DOl: $10.19195 / 2353-8546.4 .13$

AGNIESZKA MATUSIAK*

Uniwersytet Wrocławski (Polska)

\title{
Międzyrzecze kultur. Rzecz o współczesnej rosyjskojęzycznej literaturze ukraińskiej
}

The interfluve of cultures. On the contemporary Ukrainian literature written in Russian. The proposed text involves an overview of the Ukrainian literature written in Russian in the period of political transition after the collapse of the Soviet Union. The author believes that the inclusion of this type of literature in the overall literary circulation can constitute a significant step in the post-colonial process of selfupgrading of Ukrainian literature. Moreover, the author claims that the hybrid variety of Ukrainian literature should be seen not as a weakness, but a significant advantage.

Keywords: 20th- and 21st-century Ukrainian literature, Ukrainian literature written in Russian, contemporary Ukrainian literary criticism

Междуречье культур. 0 современной русскоязычной украинской литературе. Данная статья является попыткой синтетического представления русскоязычной украинской литературы в период системной транзиции после распада Советского Союза. Автор статьи убеждена, что включение этой литературы в общеукраинский литературный контекст было бы существенным звеном в процессе постколониального самосовершенствования современной украинской литературы, которая в своей гибридности должна усматривать преимущество, а не недостаток.

Ключевые слова: украинская литература XX-XXI ст., русскоязычная украинская литература, современная украинская литературная критика

* Adres do korespondencji: Zakład Ukrainistyki IFS UWr, ul. Pocztowa 9, 53-313 Wrocław. E-mail: asia3005@gmail.com

** Tekst został przygotowany $\mathrm{w}$ ramach międzynarodowego projektu badawczego NPRH $\mathrm{Nr} 12 \mathrm{H} 12004681$ „Posttotalitarny syndrom pokoleniowy w literaturach słowiańskich Europy Środkowej, Wschodniej i Południowo-Wschodniej końca XX-początku XXI wieku w świetle studiów postkolonialnych".

Miscellanea Posttotalitariana Wratislaviensia 4/2016

(C) for this edition by CNS 
Nowożytna literatura ukraińska, silnie warunkowana sytuacją historyczno-polityczną, od zarania przebiegała dwoma nurtami: rosyjskim i ukraińskim. Dość wspomnieć o spuściźnie literackiej w języku rosyjskim Iwana Kotlarewskiego, Hryhorija Kwitki-Osnow'ianenki, Jewhena Hrebinki (nota bene, mało kto dziś pamięta, że jest on autorem popularnego romansu Очи черные), Mykoły Kostomarowa, Tarasa Szewczenki, Pantelejmona Kulisza, Marka Wowczoka (Mariji Wilińskiej), Ołeksy Storożenki, Mychajła Staryckiego czy budzącego do dziś kontrowersje wśród slawistów Nikołaja Gogola/Mykoły Hohola ${ }^{1}$. W zasadzie w XIX-wiecznej literaturze ukraińskiej można mówić o bilingwizmie, wybór zaś języka, w jakim twórca pisał, zależał przede wszystkim od czytelnika, do którego utwór był skierowany. Ten warunek można traktować jako prawomocny do czasów ukazów: Wałujewa (1863) i Emskiego (1876), zabraniających (zwłaszcza w tym ostatnim, gdzie wobec kultury ukraińskiej zostały zastosowane wyjątkowo srogie obostrzenia) tworzenia w języku ukraińskim utworów innych niż takie, które byłyby osadzone w folklorze. Sprowokowało to $\mathrm{w}$ znacznym stopniu przyśpieszenie procesu narodowego dojrzewania kultury ukraińskiej w Galicji, a jego rezultatem było wyłonienie się w literaturze ukraińskiej drugiej połowy XIX wieku ukraińskojęzycznego narodnickiego paradygmatu literackiego, a na przełomie XIX i XX wieku (1890-1914) nurtu modernistycznego, także bazującego sensu stricto na języku ukraińskim. Było to swoiste przejście od „ukrainofilstwa” do „ukraińskości”. Po przewrocie październikowym 1917 roku (do lat trzydziestych XX wieku) w literaturze ukraińskiej ponownie dochodzi do sytuacji bilingwizmu językowego ${ }^{2}$. Jednak wybór języka to już nie tylko kwestia adresata, ale narodowo-kulturowy wyznacznik tożsamościowy oraz czynnik ideowy, decydujący o nastawieniu twórcy na tworzenie w nurcie sowieckiej kultury masowej (adresowanej do „pracujących mas miast i wsi”) — język rosyjski bądź kultury wysokiej (skierowanej do młodej inteligencji ukraińskiej) — język ukraiński. Po 1934 roku, w dobie socrealizmu, literatura ukraińska bazuje wprawdzie na

${ }^{1}$ Zob. И. Лосиевский, Русская лира с Украины. Русские писатели Украины первой четверти ХІХ века, Харьков 1993.

${ }^{2}$ Tu znów mamy podobną sytuacją jak w przypadku Gogola: wielu twórców urodzonych na Ukrainie w poszukiwaniu sławy na ogólnoradzieckiej arenie literackiej porzuciło Ukrainę, jednocześnie odżegnując się od kontekstu ukraińskiej genetyki kulturowej. Wystarczy choćby wspomnieć Michaiła Bułhakowa, Annę Achmatową, Konstantina Paustowskiego, Aleksandra Wertynskiego czy Arsenija Tarkowskiego i Sygyzmunda Kryżanowskiego. Choć byli też i tacy, jak np. rosyjscy futuryści rodem z Ukrainy: Dawid Burliuk czy Aleksandr Kruczenyj, których twórczość odzwierciedla genetyczne powinowactwo z piśmiennictwem ukraińskiego baroku, a zwłaszcza z XVII-wieczną poezją Iwana Wełyczkowskiego. Ciekawym przypadkiem jest także tzw. odeska plejada (Walentin Katajew, Jurij Olesza, Ilja Ilf i Jewgenij Pietrow), w której dorobku wyraźnie wybrzmiewa lokalny koloryt kulturowy (jak wiadomo, ów „lokalny koloryt” został przez Władimira Szkłowskiego, a za nim i przez wielu innych radzieckich literaturoznawców, choć niekoniecznie tylko w pozytywnym aspekcie, określony mianem południoworosyjskiej szkoły literackiej. Zob. В. Шкловский, Гамбурский счет, Москва 1990, s. 470). Można jednak odnotować również sytuacje programowego przechodzenia w odwrotną stronę: $\mathrm{z}$ twórczości w języku rosyjskim na język ukraiński, co miało miejsce w przypadku czołowych pisarzy ukraińskich takich, jak na przykład Mykoła Chwylowy, Oswald Burghardt, Ołena Teliha czy Iwan Koczerha.

Miscellanea Posttotalitariana Wratislaviensia 4/2016

(C) for this edition by CNS 
języku ukraińskim, lecz o tekstach tworzonych w tym okresie trzeba mówić przede wszystkim jako o tekstach kultury radzieckiej (zwłaszcza do odwilży chruszczowowskiej), w której skład wchodziła i literatura ukraińska, wyjątkowo „zaideologizowana", w sposób szczególny represjonowana działaniami cenzury oraz faktycznie z niemalże stuprocentową eksterminacją ukraińskojęzycznych elit (z którymi Stalin brutalnie rozprawił się jeszcze do 1937 roku, dokończenie jego dzieła zaś przyniosła II wojna światowa). Sytuacja stopniowo zaczęła się zmieniać wraz z pojawieniem się twórczości pokolenia tzw. sześćdziesiątników i postsześćdziesiątników, by z każdym dziesięcioleciem status literatury ukraińskiej pisanej po ukraińsku mógł wzrastać, owocując między innymi tak ciekawymi reprezentacjami, jak „химерна проза”, literatura undergroundu lat siedemdziesiątych, Kijowska Szkoła Poezji czy wreszcie twórczością postmodernistów. Język rosyjski wciąż jednak, w zasadzie do samego rozpadu Związku Radzieckiego, pozostawał strategicznym narzędziem imperialnej sowieckiej polityki kulturowej, mającej na celu utrzymanie literatury ukraińskiej w statusie prowincjonalnej/neomałorosyjskiej. Stąd daremnie szukać w podręcznikowych historiach literatury ukraińskiej (konstruowanych w kluczu etnicznym i językowym - tych z początku, jak też z końca XX wieku czy nawet naszego stulecia) rozdziałów kompleksowo omawiających procesy i zjawiska literackie na Ukrainie, dla których tworzywem jest język rosyjski (choć naturalnie o owocnej twórczej współpracy pisarzy „dwóch bratnich narodów słowiańskich” swego czasu napisano morze tekstów zarówno krytyczno-, jak i historycznoliterackich).

Dlatego też de facto o rosyjskojęzycznej literaturze ukraińskiej, jako fenomenie całościowym, usiłującym przemówić własnym głosem, można mówić w zasadzie dopiero po 1991 roku, a więc w okresie niezależności Ukrainy. Jednak, paradoksalnie, dopiero wydarzenia z Majdanu 2013/2014 oraz wojna $\mathrm{z}$ rosyjskim agresorem we wschodnich regionach Ukrainy sprowokowały na ogólnoukraińskim forum literackim dyskusję nad miejscem i znaczeniem ukraińskiej literatury tworzonej w języku rosyjskim $^{3}$. Przede wszystkim wynikło zasadnicze pytanie: czy utwory pisane przez ukraińskich twórców w języku rosyjskim należy zaliczać do literatury ukraińskiej, czy może jednak do literatury rosyjskiej. Do dziś nie ma jednoznacznej odpowiedzi na to pytanie, zdania są mocno podzielone i, niestety, nic nie wskazuje na to, aby w najbliższym czasie ów problem znalazł swoje „szczęśliwe” rozwiązanie ${ }^{4}$. Zwolennicy literatury ukraińskiej opartej li tylko na języku ukraińskim (np. Taras Prochaśko

${ }^{3} \mathrm{~W}$ rosyjskojęzycznym środowisku literackim próby podjęcia dyskusji na ten temat były czynione już w pierwszym dziesięcioleciu niezależności Ukrainy. Niestety, próby te zamiast w ukraińskiej przestrzeni literackiej, wciąż wybrzmiewały na rosyjskim forum literackim. Zob. И. Булкина, „Дом схимерами”: к вопросу о русской литературе Украины, „НЛО” 2000, № 5 (45), с. 282-293. Por. też: Дмитрий Кузвмин о двуязычии литературы в Украине и зарубежных аналогах, http://artmisto. net/2015/06/07/dmitriy-kuzmin-o-dvuyazyichii-literaturyi-v-ukraine-i-zarubezhnyih-analogah/ [dostęp: 7.11.2015]. W Polsce pisał na dany temat Bogusław Bakuła w książce Skrzydło Dedala (Poznań 1999, s. 35-40).

${ }^{4}$ Por. MTV zamiast pierwszego sekretarza. Z Ołeksandrem Bojczenką rozmawiają Zbigniew Rokita i Ziemowit Szczerek, http://www.kew.org.pl/wp-content/uploads/2014/12/M\%C5\%82oda_Literatura_Ukrai\%C5\%84ska.pdf [dostęp: 20.11.2015].

Miscellanea Posttotalitariana Wratislaviensia 4/2016

(C) for this edition by CNS 
i Ołeksandr Bojczenko) uważają, iż twórczość rosyjskojęzyczna sprzyja neorusyfikacji kultury ukraińskiej, a czynnik terytorialny nie może być decydujący; tym powinien być przede wszystkim język. Z kolei druga strona, to jest ukraińscy pisarze rosyjskojęzyczni, twierdzą, iż współczesne ukraińskojęzyczne życie literackie tworzy hermetycznie zamkniętą wspólnotę, niewyrażającą woli współpracy z tymi, którzy do owej wspólnoty nie należą. Są też i opinie pośrednie, próbujące dążyć do konsensusu obu środowisk. Tu cenny jest pogląd Rostysława Semkowa, charkowskiego literaturoznawcy i krytyka literackiego, uważającego, że głównym kryterium powinno być samopozycjonowanie się pisarza $\mathrm{w}$ danym kręgu kulturowo-literackim (innymi słowy autorska kulturowa autoidentyfikacja) i jako przykład podaje twórczość Andrieja Kurkowa, który choć pisze po rosyjsku, publikując zarówno w Rosji, jak i na Ukrainie oraz Zachodzie (gdzie dziś mieszka), to od samego początku bezwzględnie określa siebie jako pisarza ukraińskiego ${ }^{5}$. Iryna Sławinska, jedna z czołowych dziś ukraińskich przedstawicielek krytyki literackiej oraz osoba żywo zainteresowana nawiązaniem dialogu między środowiskami pisarzy rosyjsko- i ukraińskojęzycznych, wielokrotnie w swych wypowiedziach zwracała uwagę, że ukraińska literatura rosyjskojęzyczna jest niesłusznie niedoceniana w kręgach współczesnego ukraińskojęzycznego literaturoznawstwa i krytyki literackiej. Zwłaszcza opinia o kojarzeniu tej twórczości tylko z literaturą masową jest wyjątkowo niesprawiedliwa, albowiem tak samo jak w literaturze ukraińskojęzycznej, tak i w rosyjskojęzycznej można mówić zarówno o nurcie popularnym, jak i wysokoartystycznym czy też o ich kreatywnym symbiotycznym połączeniu w tekstach post- i postpostmodernistycznych (podobnie zresztą jak w tekstach ukraińskojęzycznych).

$\mathrm{Z}$ całą pewnością ma rację i Serhij Żadan, który po wielekroć zwracał uwagę, iż terytorium Ukrainy zamieszkują nie tylko ludzie ukraińskojęzyczni, lecz także rosyjsko- czy tatarskojęzyczni, i ich potrzebę tworzenia we własnym języku należy uszanować. Przejawem rzeczonego szacunku powinno być włączanie literatur tworzonych w owych językach do wspólnego, ogólnoukraińskiego życia kulturalno-literackiego, któremu powinna patronować idea postmodernistycznej i postkolonialnej hybrydowości.

Niemałe zasługi w zaktywizowaniu dyskusji nad miejscem i znaczeniem współczesnej rosyjskojęzycznej literatury w ukraińskim procesie literackim ma również Jurij Wołodarski, kijowski rosyjskojęzyczny poeta i krytyk literacki, związany z portalem „ШO”. Jest on inicjatorem wielu debat ${ }^{6}$ poświęconych temu zagadnie-

${ }^{5}$ Zob. Андрій Курков: „Літератори і барикади”. Автор бесіди Сергій Жадан, http://sho.kiev. ua/article/364 [dostęp: 15.08.2015], a także A. Kurkow, Ukraińska kultura może odnosić sukcesy, [w:] Raport o stanie kultury i NGO w Ukrainie, Lublin 2012, s. 149-168, http://www.nck.pl/media/study/ kopia_raportostaniekulturyingowukrainie1.pdf [dostęp: 7.11.2015].

${ }^{6}$ Zob. np. dyskusję: Російськомовна література України: бідна родичка з багатої сім'ї?, Київ 6.03.2013, http://museumshevchenko.org.ua/post.php?id=277 [dostęp: 30.10.2015], albo okrągłe stoły, które miały miejsce w ramach festiwalu „Gogolfest”, Kijów, 17.09.2013: Російськомовна література України: на двох стільизах чи між ними?, https://www.youtube.com/watch?v=KfV_WZAiPDs [dostęp: 30.10.2015]), festiwalu „Donkult” (kijowskiego - jesienią 2014 roku, http://www.dofa.fund/\#!a- 
niu, których celem było zarówno przewartościowanie podejścia do literatury rosyjskojęzycznej, jak i pokazanie, w jak paradoksalnej sytuacji znaleźli się po 1991 roku ukraińscy pisarze rosyjskojęzyczni, żyjący w „niczyjej przestrzeni pomiędzy” ukraińskim a rosyjskim życiem literackim. Z perspektywy rosyjskiej są oni postrzegani jako nierosyjscy pisarze rosyjskojęzyczni, piszący co prawda po rosyjsku, ale nienależący do rosyjskiego procesu kulturowo-literackiego ${ }^{7}$. Natomiast z perspektywy ukraińskiej pisarze ci nie należą też do ukraińskiego procesu kulturowo-literackiego. Paradoksalność położenia tych pisarzy ujawnia również inny fakt: twórcy ci, aby zaistnieć na rodzimym rynku księgarskim, muszą zaistnieć najpierw na rosyjskim bądź, jak Kurkow czy twórcy fantasy, na zachodnim rynku wydawniczym i dopiero stamtąd, poprzez sieci księgarskie, których właścicielami są Rosjanie, mogą potencjalnie trafić na półki w księgarniach ukraińskich. Potencjalnie, ponieważ tak się składa, że właściciele księgarni sieciowych na rynek ukraiński wolą dostarczać książki pisarzy nie ukraińskich, lecz rosyjskich, i to w przeważającej mierze wywodzących się ze sfery masowej literatury popularnej. Jest to ciekawe zjawisko, które wymaga oddzielnego socjologicznego zbadania i opisania. Choć w pierwszym odruchu nasuwa się nieodparta myśl, że jest to jedna $\mathrm{z}$ wielu strategii wspomnianego wcześniej mechanizmu rosyjskiego postsowieckiego neokolonizowania kultury ukraińskiej.

A panorama współczesnej rosyjskojęzycznej twórczości pisarzy ukraińskich jest bogata w swej różnorodności stylistycznej i gatunkowej. Do najbardziej znanych należy niewątpliwie Andriej Kurkow, którego książki zostały przełożone na 21 języków (w tym też na polski). Wśród innych prozaików, o których trzeba wspomnieć, są Siergiej i Marina Diaczenko, Walentyna Jermołowa, Boris Finkelsztajn, Stanislaw Sławycz, Siergiej Ponomarenko, Uliana Gamajun, Aleksiej Nikitin, Mila Iwancowa, Łada Łuzina, Ada Samarka, Jana Dubynjanska, Ołena Mordowina czy Wsiewołod Niepogodin, Aleksandr Sidorenko, Andriej Krasniaszczych, Władimir Rafiejenko. Ciekawymi autorami są również wzięci scenarzyści Jurij Smirnow i Siergiej Szu-

bout-donkult/cipc, [dostęp: 30.10.2015], a także lwowskiego - wiosną 2015 roku, http://www.dofa. fund/\#!----/c1jsg [dostęp: 30.10.2015]), czy też debaty i spotkania z pisarzami podczas lwowskiego forum wydawców w 2014 roku, http://bookforum.ua/customer/88/39.html [dostęp: 30.10.2015]. Warto tu też wspomnieć o ciekawej wydawniczej inicjatywie J. Wołodarskiego i Ludmiły Ulickiej, a mianowicie o publikacji w moskiewskim wydawnictwie „Три квадрата” tomiku 18 opowiadań o wojnie rozgrywającej się aktualnie na wschodzie Ukrainy. Autorami opowiadań są ukraińscy pisarze i rosyjskojęzyczni, i ukraińskojęzyczni (S. Żadan, A. Bondar, Jurija Wynnyczuk, K. Arutiunowa, W. Rafiejenko, Ł. Denysenko, W. Jeszkilew, E. Swiencickaja, J. Andruchowycz, T. Prochaśko, A. Krasniaszczych, Ada Samarka, T. Malarczuk, J. Kononenko, J. Kulikowski, W. Łys, N. Śniadanko). Zob. Небо этого лета. Рассказы украинских писателей, состав. Ю. Володарский, Москва 2015.

${ }^{7}$ W takim kontekście twórczość rosyjskojęzycznych pisarzy ukraińskich z rosyjskiej perspektywy nieuchronnie zostaje skazana na pograniczny byt kolonialnej mimikry, w której świetle, jak pisał za Lacanem Bhabha, skolonizowany jest prawie taki sam jak kolonizator, ale nie całkiem. Zob. H.K. Bhabha, Miejsca kultury, tłum. T. Dobrogoszcz, Kraków 2010, s. 79-88. 
czenko. Z kolei spośród dramaturgów nie można pominąć Aleksandra Mardania, Marii Łado, Maksima Kuroczkina czy Natalii Worożbyt.

Natomiast grono ukraińskich poetów rosyjskojęzycznych reprezentują między innymi: Borys Chersonski, Aleksandr Kabanow, Natalia Bielczenko, Aleksandr Ratner, Anastasija Afanasiewa, Aleksandr Mocar, Łeonid Boroziencew, Jewgienia Czuprina, Irina Jewsa czy Igor Pomierancew (mimo że od 1978 roku mieszkający na stałe w Wielkiej Brytanii, to niezmiennie aktywnie uczestniczący w życiu literacko-artystycznym Ukrainy). Do grona wymienionych poetów zwykło się zaliczać także interesującego poetę mieszkającego na Krymie Andrieja Polakowa. Jednak aneksja Krymu i działania wojenne w Donbasie sprowokowały redefinicję autoidentyfikacji twórcy, który w jednym $\mathrm{z}$ wywiadów wyznał, że właściwie od zawsze uważał, iż to Rosja jest jego ojczyzną, a on sam jako pisarz plasował się w rosyjskiej semiosferze kulturowej ${ }^{8}$. Podobną woltę tożsamościową wykonał charkowski poeta Stanislaw Minakow oraz niegdysiejszy lider ługańskiego ugrupowania literackiego „Стан” Aleksandr Sigida. Poeta na początku 2015 roku na portalu День литератури ogłosił powstanie nowej literackiej organizacji Neolit (Неолит), której istotą jest tworzenie noworosyjskiej literatury ${ }^{10}$.

Po 1991 roku na Ukrainie ukazało się kilka antologii promujących twórczość - przeważnie poezję - wymienionych autoró $w^{11}$. Czytelnik z dorobkiem przywołanego kręgu pisarzy może także zapoznać się poprzez internetowe portale literackie i czasopisma ${ }^{12}$, z których część wychodzi również w wersji elektronicznej. Obecnie za najbardziej opiniotwórczy w tym aspekcie należy uznać kijowski portal „SZO” („ШO”), którego twórcą i redaktorem naczelnym jest Aleksandr Kabanow. Portal, istniejący od 2005 roku (http://sho.kiev.ua/), pierwotnie pomy-

${ }^{8}$ Zob. Андрей Поляков: „Я не знаю, что такое быть русским”. Глеб Морев поговорил с бывшим украинским, а ныне российским поэтом о поисках национальной идентичности, 29 maja 2014, http://www.colta.ru/articles/literature/3386 [dostęp: 7.11.2015].

9 Organizacja literacka „Стан” istniała w Ługańsku od 1999 roku. Oprócz Sigidy należeli do niej: Jelena Zasławska, Jarosław Minkin, Olga Rudenko, Lubow Jakymczuk, Konstantin Skorkin. Z ugrupowaniem tym sympatyzowali także Serhij Żadan czy tragicznie zmarły Jurko Pokalczuk.

10 А. Сигида, „Неолит” или „Новороссийская Литература”. Манифест, http://denlit.ru/ index.php?view=articles\&articles_id=383 [dostęp: 7.11.2015].

11 Zob. Какие мьь? Попробуем понять... Киевская школа русской поэзии, состав. А. Потапова, Киев 1996; Антология современной русской поэзии Украины, состав. М. Красиков, Харьков 1998; Дикое Поле: Стихи русских поэтов Украины конца ХХ века, сост. А. Дмитриев, Харьков 2000; Дом с химерами: поэтический сборник, состав. М. Муляр, Л. Финкельштейн, Киев 2000; Enter/Книга донецкой прозы, Донецк 2001 (teksty zarówno rosyjsko-, jak i ukraińskojęzyczne); Киев. Русская поэзия. ХХ век. Поэтическая антология, состав. Ю. Каплан, Киев 2003; Киевская Русъ. Современная русская поэзия Украины. Антология, состав. Ю. Каплан и О. Бешенковская, Мюнхен-Гельзенкирхен 2003.

12 Więcej o ukraińskich rosyjskojęzycznych czasopismach po 1991 roku zob. И. Булкина, Литературные журналы Украины: в поисках жанра, http://old.russ.ru/krug/19990902_bulkina.html [dostęp: 30.10.2015] oraz: А. Грязов, Русская поэзия Украины от а до я. Попытка энциклопедии, https://www.stihi.ru/2004/09/24-1038 [dostęp: 30.10.2015]. 
ślany był jako platforma dla rosyjskojęzycznego środowiska literackiego. Jednak z czasem otworzył swoje "podwoje” także na publikacje pisarzy i krytyków literackich ukraińskojęzycznych. Nie można też zapomnieć o czasopismach literackich takich, jak: kijowska „Те̨сza” („Радуга”, http://raduga.org.ua/), na którego czele stoi Jurij Kowalski, oraz donieckie „Dzikie Pole” („ДикОе поле”), którego redaktorem naczelnym jest Aleksandr Korabliow (http://www.dikoepole.org/). Spośród innych projektów warto przypomnieć dniepropietrowski „ТЕРМИтник поэзии” (http:// main.termitnik.ru/?_ga=1.208917844.71957596.1447411131) Władimira Szewczuka oraz „Obłok w Wierszach” („Облако в стихах”) Ilji Kozaczenki z Kijowa, a także kijowski portal Nikołaja Podgornego „Вирши.Киев.uа”, „Каштановый дом” Andrieja Grazowa, „13-ая альтернатива” Nikołaja Rumiancewa, jak również „VAKh Online": http://vakh.online.com.ua/library/ (www.kharchenko.com) kijowskiego poety Władimira Charczenki.

Współczesna literatura rosyjskojęzycznych pisarzy ukraińskich została też zaprezentowana w obu edycjach Narodowego Forum Kulturalnego „Donkult - Artystyczne Zagłębia” („Донкульт - Мистецькі Надра”), które po raz pierwszy odbyło się w Kijowie na przełomie października i listopada 2014 roku, natomiast po raz drugi - we Lwowie w czerwcu 2015 roku. „Donkult”, zarówno ten kijowski, jak i lwowski, obejmował kilkadziesiąt różnych wydarzeń, w tym wystawy artystyczne, projekcje filmów, koncerty, spotkania z pisarzami oraz wykłady i debaty. Celem obu forów, jak anonsowali sami organizatorzy, było przedstawienie osiągnięć kulturalno-naukowych Donbasu. Pierwsza edycja „Donkultu” wzbudzała mieszane uczucia. Z jednej strony odnosiło się wrażenie, jakby sami przedstawiciele prezentowanej donbaskiej kultury i nauki chcieli powiedzieć: „Zobaczcie, nie jesteśmy tylko lumpenproletariatem, też mamy swoje środowiska intelektualne". Natomiast z drugiej strony jakby pozostała część Ukrainy chciała poprzez tę wystawę wykonać swoisty rewerans i powiedzieć: „Pamiętamy o was, kochamy was”. Być może był to swoisty symboliczny gest przeprosin za wieloletni brak dobrej woli, by chcieć pamiętać i zrozumieć złożoną specyfikę tego regionu ${ }^{13}$, który niewątpliwie ma historycznie ważne znaczenie dla całej kultury ukraińskiej ${ }^{14}$. I niestety, trzeba było wojny, by mogło dojść do symbolicznego gestu pojednania, które poprzez miejsce edycji drugiego forum - Lwów, reprezentujący zachodnią Ukrainę - nabrało jeszcze większego znaczenia. A to przecież właśnie z Donbasem są związane tak znaczące postacie kultury ukraińskiej, jak: w latach dwudziestych XX wieku Mykoła Skrypnyk, autor ukraiń-

13 Zob. T.A. Olszański, Co ujawniła Rewolucja Godności, „Kultura i Społeczeństwo” 2015, nr 2, s. 215-226. Por. też ciekawy wywiad pt. Donbas było stać tylko na oszustów i złodziei. Ołeksij Czupa w rozmowie z Pawłem Pieniążkiem, http://www.krytykapolityczna.pl/artykuly/ukraina/20141218/ czupa-donbas-bylostac-tylko-na-oszustow-i-zlodziei [dostęp: 20.11.2015]; I. Дзюба, Донецька рана України: Історико-культурологічні есеї, Київ 2015, ss. 78.

14 Zob. А. Витковски, Пятилетка без плана: Украина: 1991-1996: Формирование национального государства, экономика, элиты, пер. с нем. Н. Комаровой, Киев 1998, s. 23-57. Г. Куромія, Свобода і терор у Донбасі: Украйнсько-російське прикордоння, 1870-1990-і роки, пер. з англ. Г. Кьорян, В. Агеев, Київ 2012. 
skiej wersji polityki ukrainizacyjnej; jeden z czołowych poetów dwudziestowiecznej literatury ukraińskiej Wołodymyr Sosiura; Kost' Herasymenko, Hryhorij Bahliuk, Wasyl Hajwaronski, tworzący ugrupowanie „Забой”, które w drugim dziesięcioleciu minionego wieku kreatywnie i efektywnie włączyło się w akcję ukrainizacji Donbasu. Z tamtej części Ukrainy pochodzą także kluczowe postacie tak zwanych sześćdziesiątników, to jest Iwan Dziuba, Iwan Switłycznyj, Wasyl Hołoborodz'ko oraz Wasyl Stus, uważany za kongenialnego poetę ukraińskiego drugiej połowy XX wieku. Warto pamiętać również o emigracyjnych twórcach urodzonych na Donbasie, takich jak: poeta, publicysta i krytyk literacki Łeonid Łyman (USA) czy prozaik i dziennikarz Witalij Bender (Wielka Brytania) oraz poetka i malarka Emma Andijewska (związana niegdyś z „Grupą Nowojorską”, a obecnie mieszkająca w Niemczech).

Spośród aktualnie tworzących na Ukrainie pisarzy o donbaskich korzeniach nie można pominąć Ireny Rozdobudz'ko, autorki popularnej prozy kobiecej, która od dłuższego czasu bije rekordy czytelniczej popularności, jak też pochodzącego z Makijiwki Ołeksija Czupy, autora głośnych aktualnie powieści Bezdomni Donbasu, Dziesięć słów o ojczyźnie oraz Bajki z mojego schronu (wszystkie książki wydane w 2014 roku). Jednakże z całą pewnością rola „lidera” przypada Władimirowi Rafiejence - autorowi takich utworów prozatorskich, jak: Krótka książka pożegnań (2000), Wakacje czarowników (2005), Czasowniki bezzwrotne (2009), Moskiewskie divertimento (2011), Demon Kartezjusza (2013), oraz tomików poetyckich Trzy dni z tygodnia (1998), Prywatny sektor (2002) i Przeprawa przez droge (2003). Pisarz w 2014 roku z powodu działań wojennych zmuszony był opuścić rodzinny Donieck i zamieszkać w Kijowie. Twórczość Rafiejenki stanowi najjaskrawsze odzwierciedlenie skomplikowanej sytuacji współczesnej ukraińskiej literatury rosyjskojęzycznej. Rosyjskiemu czytelnikowi jego pisarstwo może wydawać się lokalne, a nawet nieco egzotyczne analogicznie jak każda inna literatura napisana po rosyjsku, acz osadzona w realiach innego kraju, co więcej: innej mentalności. Jednakże wychowanek samego „serca górniczego Donbasu", piszący o mieście Z. (dla którego prototypem był współczesny Donieck ${ }^{15}$ ), nie wpasowuje się również w ukraińskie ramy literackiego landszaftu. Autor Demona Kartezjusza jest więc mieszkańcem swoistego międzyrzecza, egzystującym na skrzyżowaniu literatury ukraińskiej i rosyjskiej. Stąd geograficzna przynależność Rafiejenki nie ma odniesienia ani do „Rosyjskiej Nagrody”, którą ten otrzymał w 2013 roku właśnie za Demona Kartezjusza ${ }^{16}$ (z kolei w 2012 roku jego

15 Zob. B. Рафеенко, Абрикосы Донбасса, „Русский журнал” 2014, 30 мая, http://www.russ. ru/pole/Abrikosy-Donbassa [dostęp: 20.11.2015].

${ }^{16}$ Warto podkreślić, że Demon Kartezjusza, stając w szranki „Rosyjskiej Nagrody”, znalazł się w jednym szeregu z takimi utworami, jak Fabryka „Wolność” Ksenii Bukszy, Tellurium Władimira Sorokina czy Miłość do trzech zukerbrinów Wiktora Pielewina. W powieści Rafiejenki odnajdujemy i mroczne proroctwo, które się spełnia (konkurencja dla Sorokina?), i ciąg zaskakujących osobowościowych transformacji w wyniku aktu „migotania” (Pielewin ze swoimi „pociągami losu” włącza w podobny proces przeobrażeń wszystko i wszystkich). I oczywiście industria: zmitologizowane, jednak absolutnie rozpoznawalne, Donieckie Zakłady Metalurgiczne z Demona Kartezjusza, oraz na odwrót, całkowicie anonimowa, acz zobrazowana w duchu socrealistycznej powieści produkcyjnej fabryka 
powieść Moskiewskie divertimento zajęła drugie miejsce w kategorii „Duża Proza” tej samej „Rosyjskiej Nagrody”), ani do krótkiej listy nagrody „NOS” z 2014 roku ${ }^{17}$.

Reasumując, myślę, że warunkiem sine qua non zmiany statusu współczesnej rosyjskojęzycznej literatury ukraińskiej jest w pierwszej kolejności usprawnienie komunikacji między ukraińsko- i rosyjskojęzycznym środowiskiem literackim, ich faktyczne porozumienie się, regularne wspólne inicjatywy artystyczno-literackie, wspólne publikacje. Poza tym za niezbędne w tym aspekcie uważam także efektywne wsparcie ze strony krytyki literackiej oraz literaturoznawców, którzy podjęliby się wnikliwego synchronicznego i diachronicznego oglądu tejże literatury przez pryzmat jej jakości, tego, co ta ma do powiedzenia w sensie artystycznym - na temat tego, co mówi i jak mówi (także à propos tożsamości), a nie przez pryzmat języka, w którym jest pisana ${ }^{18}$. Nie bez znaczenia byłaby też jej promocja w optyce wolnej od okołoliterackich kontekstów, które na literaturę tę rzucały (i nadal rzucają) fałszywe światło. Literatura ta powinna zostać wprowadzona w ogólnoukraiński obieg wydawniczo-literacki i poddana reinterpretacji. Wiązałoby się to nie tylko z zamiarem umożliwienia ukraińskojęzycznemu czytelnikowi zrewidowania swojego poglądu na nią. Działania te stanowiłyby istotne ogniwo w procesie dekolonizacji literatury czy też szerzej - kultury ukraińskiej ${ }^{19}$. Tego typu strategia byłaby również znaczącym gestem w procesie postkolonialnego autodoskonalenia się literatury ukraińskiej, która ze swej hybrydowej różnorodności winna uczynić nie słabość, lecz siłę mogącą stanowić skuteczny oręż w odpieraniu neokolonizujących aspiracji płynących wobec niej z Rosji, której w ramach prowadzonej przez siebie agresywnej neoimperialnej polityki kulturowej zależy na konsekwentnym utrzymywaniu literatury ukraińskiej w dziedzictwie kolonialnym. Dlatego też — poprzez wiele symbolicznych i realnych dyskursów oraz praktyk neoimperialnych/neokolonialnych — umiejętnie podsyca i kontroluje napięcie między rosyjsko- i ukraińskojęzycznymi dyskursami literackimi na Ukrainie. Stąd utrzymywanie przez ukrainistyczny dyskurs krytycznoliteracki i literaturoznawczy wyalienowania rosyjskojęzycznej literatury ukraińskiej z ogólnokrajowej przestrzeni literackiej oznacza pozostawianie ukraińskiej literatury w zależności od dyskursu narzucanego z Rosji. Co więcej, oznacza owego dyskursu

zbrojeniowa z nośną w swej symbolice nazwą „Wolność” w powieści Bukszy. Por. A. Грувер, Письмо из города Z. Опьт провинциального прочтения (Владимир Рафеенко. „Демон Декарта”), „Новый Мир" 2015, nr 1, http://magazines.russ.ru/novyi_mi/2015/1/16guv.html [dostęp: 20.11.2015].

${ }^{17}$ NOS - nagroda literacka Fundacji Michaiła Prochorowa, przyznawana co roku pisarzom rosyjskojęzycznym za nowatorski wkład w rozwój literatury rosyjskiej/rosyjskojęzycznej.

18 Por. Б. Херсонский, Язык мой - враг мой, или Игры на чувстве ущемленности, http://life. pravda.com.ua/columns/2015/11/23/203612/ [dostęp: 25.11.2015].

${ }^{19}$ Por. A. Loomba, Kolonializm / Postkolonializm, tłum. N. Bloch, Poznań 2011, s. 108. 
wzmacnianie i umacnianie, będące swoistym autowpasowywaniem się w kulturowy rytuał neoimperium Rosyjskiego Miru $^{20}$.

Zresztą, czytając teksty pisarzy rosyjskojęzycznych, autodefinujących siebie jako twórców ukraińskich, odnosi się wrażenie, że w pisarstwie swoim stawiają oni akcent na kreatywną hybrydowość, w myśl której język rosyjski jest przez nich kształtowany zgodnie z własnymi doświadczeniami, a nie odwrotnie. Sądzę, że działa tu ten sam odruch, co w przypadku między innymi Chinui Achebe, nigeryjskiego pisarza, który, decydując się na tworzenie w języku angielskim, tak oto pisał o swej decyzji:

[...] dla mnie nie ma innego wyboru. Otrzymałem ten język i mam zamiar go wykorzystać. [...] Czuję, że język angielski będzie w stanie udźwignąć ciężar moich afrykańskich doświadczeń. Ale będzie to musiał być nowy angielski, pozostający wprawdzie w pełnej komunikacji z domem jego przodków, ale zmieniony tak, aby pasował do nowego afrykańskiego kontekstu ${ }^{21}$.

Jestem przekonana, że afirmatywna, acz niebezkrytyczna (sic!) zmiana podejścia do rosyjskojęzycznej literatury ukraińskiej przyczyniłaby się do skuteczniejszego i bardziej autentycznego (niż obraz kreowany obecnie) wyartykułowania — zarówno na kulturalno-literackiej arenie wewnątrzkrajowej, jak i zagranicznej — wieloaspektowego bogactwa współczesnej literatury ukraińskiej.

${ }^{20} \mathrm{~W}$ tym świetle nieodparcie nasuwa się też pytanie, czy pisarstwo w języku ukraińskim jest już $\mathrm{z}$ samej definicji ucieleśnieniem kondycji postkolonialnej? Czy ono nie rezonuje $\mathrm{z}$ formami i ideami kolonialnej przeszłości, będąc naznaczonym piętnem kolonialnych następstw, stanowiących tym samym problem dla ukraińskiej tożsamości kulturowej? Myślę, że to pytania z natury retorycznych, ale w poruszanym tu aspekcie warto stale je mieć na uwadze.

${ }^{21}$ Cyt. za: A. Loomba, op. cit., s. 106. 